\title{
'BENEFICIARY' AS A MEANS FOR A DICHOTOMOUS REPRESENTATION IN POLITICAL DISCOURSE
}

\author{
Marek Hampl
}

\begin{abstract}
This paper focuses on the employment of the participant role 'Beneficiary: Recipient' in the discourse of U.S. President George W. Bush in the period from September 11, 2001 to May 1, 2003. The analysis presented in the paper has been conducted on the corpus of 92 speeches delivered by the speaker. The aim of the paper is to observe the formation of the 'Us' and 'Them'groups on the basis of the involvement of the participant 'Beneficiary: Recipient'. The theoretical framework for the analysis is grounded in the system of transitivity developed by M. A. K. Halliday. In the analytical part, the focus will be placed on the analysis of the participant 'Beneficiary: Recipient' that is involved in Material processes in George W. Bush's discourse. It will be argued that the employment of this participant also contributed to positive presentation of 'Us' and to negative presentation of 'Them'.
\end{abstract}

\section{Keywords}

beneficiary, transitivity, material process, political speech, George W. Bush

\section{Introduction}

As a consequence of 9/11, there developed a specific type of discourse aimed at the justification of military operations in Afghanistan and in Iraq. In this process, the division into the 'Us and Them' camps provided an effective strategy for the legitimisation of both military operations. This paper focuses on the discursive construction of the 'Us' and 'Them' groups in the discourse of George W. Bush after September 11, 2001. Butt, Lukin and Matthiessen (2004: 268) observe that after 9/11, "there was an explosion of discourses within a multitude of different registers". Within this broad range of registers, the focus is placed on political speeches delivered by George W. Bush in the period from September 11, 2001 to May 1, 2003 when the major combat operations in Iraq officially ended. Thompson (2013: 226) suggests that political speeches "represent one of the most overt ways in which socio-cultural ideologies are projected". Political speeches that are analyzed presented an official stance of the Bush administration towards international political affairs from September 11, 2001 to May 2003 and they include the speeches delivered in the period of time when there was a need to clearly distinguish between 'Us' (represented by the 
USA and its allies) and 'Them' (the regimes in Iraq and Afghanistan, terrorist networks). In political speeches which result from such a "binary opposition" (Hodges 2011: 66), it may be expected that certain linguistic patterns will be emphasized with the aim to provide information about respective social actors (Van Leeuwen 1996) and their actions.

The aim of the paper is to explore the dichotomous representation of the 'Us' and 'Them' groups on the basis of the employment of the participant role 'Beneficiary: Recipient' in the speaker's discourse. The analytical part of the paper focuses on the formation of dichotomous representation that could be also conveyed with the involvement of the participant Beneficiary: Recipient that participates in Material processes in the system of transitivity. George W. Bush employed this participant in his discourse in the process of rhetorical preparation of the military operations, both in Afghanistan and in Iraq, and also in the course of both military operations. In the process of analysis, an attempt will be made to isolate the patterns of transitivity that present the involvement of various social actors (the USA, the citizens of Iraq and Afghanistan, the Taliban, the Iraqi regime, terrorists) in Material processes in their roles of the Beneficiaries, Actors and in the Goals of their actions.

In George W. Bush's discourse, the USA is portrayed as the source of humanitarian assistance and support for the civilian population of Afghanistan and Iraq that takes the role of the Beneficiary: Recipient. On the other hand, 'They' are responsible for the harsh treatment of the Beneficiaries: Recipients in Afghanistan and Iraq. Also, 'They' (more specifically, the Iraqi regime) are in their actions focused on providing help to the Beneficiaries: Recipients who are associated with terrorism and who could benefit from various activities and sources, which increases the potential of the enemies to threaten the USA. As a result, the 'Us' and 'Them' camps could "emerge as meaningful categories" (Oddo 2011: 288).

The theoretical framework for the analysis is grounded in the system of transitivity, which is a part of the ideational metafunction of language proposed by Halliday (1967a, 1967b, 1976, 1985, 2014). According to Halliday (1967b: 199), transitivity is "the set of options relating to cognitive content, the linguistic representation of extralinguistic experience, whether of phenomena of the external world or of feelings, thoughts and perceptions". The theoretical framework also discusses the nature of Material processes and the participant roles in Material processes - the Actor, the Goal and the Beneficiary. Halliday (1967a: 53) notes that the Beneficiary is "that which benefits from the process expressed in the clause". As regards the status of the Beneficiary, Fowler (1991: 98) observes that the Beneficiaries have "less powerful semantic role". However, the Beneficiaries 
may also present certain extent of their power, for example, when the Actors are activated to provide help or assistance for Beneficiaries, they may subsequently benefit from the realized processes.

\section{Theoretical framework - the system of transitivity}

In Halliday's Systemic-Functional Linguistics (SFL), language is organized into interpersonal, textual and ideational metafunction. Transitivity is an essential element of the ideational metafunction of language. Halliday (1976: 159) defines transitivity as the "representation in language of PROCESSES, the PARTICIPANTS therein, and the CIRCUMSTANTIAL features associated with them" (capitals in the original). Fontaine (2013: 73) notes that transitivity is an "important concept often working as the foundation for any analysis within a SFG framework". The analysis of the system of transitivity, including processes, participants and circumstances may uncover the features of texts related to the representation of social actors, their power, or responsibility for particular actions. Halliday (1985: 101) observes that "transitivity specifies the different types of processes that are recognized in the language, and the structures by which they are expressed". According to Halliday (2014: 213) "each process constitutes a distinct model or schema for construing a particular domain of experience". The main processes of the system of transitivity are Material, Mental and Relational processes. In addition to the main processes, there are, according to Thompson (1996: 96), "three less central types which can be distinguished on the basis of the usual combination of semantic and grammatical criteria". These processes are Behavioural, Verbal, and Existential.

\subsection{Material processes and overview of participants in Material processes}

Material processes are characterized by the involvement of physical action. According to Matthiessen (2015: 345), Material clauses present "clauses of 'doing - \& - happening' - actions, activities, events and the like, where an input of energy is needed to initiate the unfolding of the process". In Material processes, the following participant roles may be present: Actor, Goal, and Beneficiary.

The Actors may be seen as the initiators of actions and usually those responsible for particular activities. According to Halliday (2014: 224) the Actor is "the source of the energy bringing about the change". Therefore, the Actors are regarded as powerful entities.

Goals most usually take the form of direct objects and the processes in which the Actors are involved are aimed at Goals. Halliday and Matthiessen (1999: 167) suggest that "the Goal is impacted in some way by its participation in the process; the 'impact' either (i) brings a participant into existence or else 
(ii) manipulates one that already exists". Goal is the participant that comes into being as a result of the process or it may exist before the action is performed and it is impacted by the Actor's participation.

\subsubsection{The Beneficiary in Material processes}

In addition to the Actor and the Goal, there may be another participant in Material processes - the Beneficiary. The role of the Beneficiary in grammar is that of an indirect object. In the system of transitivity, it takes the role of an entity that benefits from the action that is performed. Halliday (1985: 132) defines the Beneficiary as "the one to or for whom the process is said to take place". Martin, Matthiessen and Painter (1997: 103) state that the Beneficiary is "a participant benefiting from the doing (the one given to or done for)". Thus, the Beneficiary may also take the advantage from the processes or actions that occur and it may also have the ability to invoke such processes. The Beneficiaries are not able to directly impact other participants in discourse and they are linked to more powerful participants, such as the Actors. Prototypical verbs that may occur with the Beneficiary include give, bring, lend, buy, send, etc.

There are two subdivisions of the Beneficiary in Material processes: a Recipient and a Client. Halliday (2014: 237) notes that the two types of the Beneficiary "resemble one another in that they construe a benefactive role; $[. .$.$] they represent$ a participant that is benefitting from the performance of the process, in terms of either goods or services." As regards the degree of participanthood, Halliday and Webster (2014: 135) suggest that a Recipient is "more fully a participant" than a Client that is "more restricted" (ibid.). Recipient as well as Client may be introduced with prepositions but also without them - Recipient usually occurs with the preposition to and Client with the preposition for. According to Halliday (2014: 239), Recipient also participates in the 'giving' model in the system of transitivity. This model presents a framework for "construing the experience of transfer of possession" (ibid.). The "giving framework" is based on the following pattern: "Actor + Process + Goal + Recipient" (ibid.). Halliday (2014: 238) observes that the Recipients participate "only in 'transitive transformative' clauses of the 'extending' type and within that category, they occur with those clauses that denote a transfer of the Actor's possession of goods - transfer to the Recipient". In such cases, "[t]he Goal represents the 'goods' being transferred" (ibid.). Thus, the Beneficiaries: Recipients may also obtain benefits from the Goals of the processes performed by the Actors. 


\section{Description of register of George W. Bush's political speeches}

Register of discourse is an established model of grammar and vocabulary and it represents contextual aspects of meaning. According to Thompson (2013: 226), "a register represents recurrent patterns of choice from the system found in texts in the environment of recurrent and culturally recognizable situations". Halliday (1978: 31, 60-65) notes that there are three dimensions in any social situation that are of linguistic importance for the situation itself. These are 'tenor' (it specifies the social roles between participants in discourse), 'mode' (the role that language plays and the medium - spoken/ written) and 'field' (the content of discourse). The following table presents the description of register of the speeches delivered by George W. Bush.

FIELD OF DISCOURSE formulating the response of the Bush administration to the events from 9/11, adding judgements about the enemies ('Them') and their actions, assuring the citizens of the USA that the country is still strong, creation of the in-group solidarity with the 'Us' group, explaining why to initiate military operations in Iraq and Afghanistan, presenting 'Us' as active agents, creating negative image of the 'other'

TENOR OF DISCOURSE Social relation: the distribution of power between the speaker and his listeners is unequal, it is grounded in the institutional status of the speaker; there is little or no direct interaction between the speaker and receivers of his discourse, there are occasional interruptions by the members of the audience or applause

MODE OF DISCOURSE Role of language: language is used as a reflection of the events that took place on $9 / 11$ and it is used as a part of the action against the enemies as well

Medium: combination of written and spoken mode, the speaker's speeches are written to be read aloud, they are not spontaneous, but planned, drafted and rewritten in advance

Table 1: The description of register of political speeches delivered by the speaker (Hasan 1999, as quoted in Urbach 2013: 304)

In terms of mode, the nature of the speeches given by George W. Bush may be described as 'pre-scripted', as they mostly involved a degree of preparedness. In pre-scripted speeches, political actors (and the teams of writers) are "involved in the organization and selection of each lexical item and each syntactic construction in an effort to achieve the maximum required effect on the audience" (Wilson 1990: 60). Similarly, Thompson (2013: 233) suggests that "speeches are generally carefully crafted and the organisation has to be maintained over longer stretches of discourse". Thus, in pre-scripted political speeches, there is a particular focus on the choice of the constructions that "strengthen" the effect of speeches. 


\section{Data for analysis and the analytical approach}

The analysis presented in this paper has been conducted on the corpus of political speeches delivered by George W. Bush in the period from September 11, 2001 to May 1, 2003. In this period of time, the speaker attempted to discursively justify the military operations overseas (in Afghanistan in October 2001 and in Iraq in March 2003) and to create a dichotomous representation between 'Us' and 'Them'. The aspect related to dichotomous representation has provided the rationale for the selection of the speeches that were delivered by the speaker.

Within the period of time from September 11, 2001 to May 2003, the focus was placed on the rhetorical preparation of two military campaigns - there was a lead up to the military operation in Afghanistan and also a lead up to the war in Iraq. It is in this period of time that the most intensive rhetorical preparations for the military actions took place. The selected speeches also contain elements of "call to arms" (Graham, Keenan \& Dowd 2004) rhetoric that is evoked by the speaker. In his speeches, George W. Bush drew on the following components of "call to arms" rhetoric: "an evil and aberrant Other; and a unifying construct" (Graham, Keenan \& Dowd 2004: 6) that was related to the representation of the 'Us' group. These features of "call to arms" rhetoric have also been relevant in the process of compiling the corpus.

Overall, 92 political speeches delivered by George W. Bush in the given period were analysed and the total amount of data for the study contains 148,292 words. The transcripts of the speeches are available on the official website of the White House (georgewbush-whitehouse.archives.gov). It could be stated that the content of the speeches represents general schemes and patterns for the creation of the dichotomy between 'Us' and 'Them' that is present across the corpus. The speeches originate from the speaker who intends to carry out policies influenced by particular ideological stances - particularly the ideology of a strong polarization into two opposing camps, which can be also based on the differences in "social, political and moral terms" (Leudar, Marsland \& Nekvapil 2004: 243).

In order to explore the representation and construction of the 'Us' and 'Them' camps in George Bush's political speeches with the help of the system of transitivity, it will be attempted to investigate the role of the participants in Material processes with whose employment the nature of identities such as 'Us' and 'Them' was created and presented in George W. Bush's political speeches. For this purpose, the participant roles in Material processes such as the Beneficiary, the Actor, and Goal are used as analytical tools.

The nature of analysis in the study is qualitative - within the analysis itself the focus was placed on the patterns of transitivity that feature the involvement 
of the participant Beneficiary: Recipient in Material processes together with the Actors and Goals. Other participants and processes that are featured in the clauses are identified as well, together with Circumstances of various types. The analysis is divided into two sections which are focused on 'Our' and 'Their' actions towards respective Beneficiaries: Recipients.

\section{Analysis and discussion - the analysis of the participant Beneficiary: Recipient in George W. Bush's discourse}

\section{1 'Us' in the role of the Actors in Material processes - the people of Afghanistan and Iraq in the participant roles of the Beneficiaries: Recipients}

The following discussion deals with the representation of the participant Beneficiary: Recipient in Material processes in which the USA takes the role of the Actor. The speaker made use of the participant Beneficiary: Recipient in the process of rhetorical preparation of the military operations in Afghanistan and in Iraq and also during the course of both military operations. The receivers of the actions (i.e. the Beneficiaries: Recipients) performed by the USA are ordinary people in Afghanistan and in Iraq. By employing the participant Beneficiary: Recipient, President Bush conveys the willingness to use the resources of the USA for the people who need them, demonstrates the effort to stabilize the humanitarian situation in the regions where the military operations took place and he also expresses solidarity with ordinary people in Afghanistan and in Iraq. At the same time, the Beneficiaries: Recipients present certain amount of their power because the actions are performed mainly for them, although they are relatively passive as far as their activity is concerned. In the following examples, the USA (in the role of the Actor) is presented in Material processes with the Beneficiaries: Recipients and with respective Goals of its actions.

(1) As we [Actor] strike [Pr. Material] military targets [Goal], we [Actor] will also drop [Pr. Material] food, medicine and supplies [Goal] to the starving and suffering men and women and children of Afghanistan. [Beneficiary: Recipient] (George W. Bush, Oct. 7, 2001)

(2) Our forces [Actor] are delivering [Pr. Material] food and water [Goal] to grateful Iraqi citizens [Beneficiary: Recipient] in Safwan and Umm Qasr. [Circumstance: Location - place] (George W. Bush, Mar. 29, 2003) 
(3) And as we and our coalition partners [Actor] are doing [Pr. Material] in Afghanistan [Circumstance: Location - place], we [Actor] will bring [Pr. Material] to the Iraqi people [Beneficiary: Recipient] food and medicines and supplies and freedom. [Goal] (George W. Bush, Jan 28, 2003)

(4) By our resolve [Circumstance: Manner], we [Actor] will give [Pr. Material] strength [Goal] to others. [Beneficiary: Recipient] (George W. Bush, Oct. 7, 2001)

(5) By our courage [Circumstance: Manner], we [Actor] will give [Pr. Material] hope [Goal] to others. [Beneficiary: Recipient] (George W. Bush, Oct. 7, 2001)

(6) We [Actor] have brought [Pr. Material] tons of food and medicine [Goal] to the Afghan people. [Beneficiary: Recipient] (George W. Bush, Dec. 7, 2001)

(7) We [Actor] are delivering [Pr. Material] emergency rations [Goal] to the hungry. [Beneficiary: Recipient] (George W. Bush, Apr. 3, 2003)

(8) We [Actor] 've sent [Pr. Material] food and medical shipments [Goal] to the suffering people of Afghanistan. [Beneficiary: Recipient] (George W. Bush, Jan. 23, 2002)

(9) We [Actor] will provide [Pr. Material] immediate humanitarian assistance [Goal] to the people of Afghanistan. [Beneficiary: Recipient] (George W. Bush, Dec. 12, 2001)

(10) We [Actor] will deliver [Pr. Material] medicine [Goal] to the sick [Beneficiary: Recipient] and we [Actor] are now moving [Pr. Material] into place [Circumstance: Location - place] nearly 3 million emergency rations $($ Goal $)<$ to feed [Pr. Material] the hungry>. [Goal] (George W. Bush, Mar 26, 2003)

(11) We [Actor] will bring [Pr. Material] freedom [Goal] to others [Beneficiary: Recipient] and we [Actor] will prevail. [Pr. Material] (George W. Bush, Mar. 19, 2003)

(12) We [Actor] 're offering [Pr. Material] help and friendship [Goal] to the Afghan people. [Beneficiary: Recipient] (George W. Bush, Oct. 6, 2001)

(13) Conditions permitting, we [Actor] will bring [Pr. Material] help [Goal] directly [Circumstance: Manner] to the people of Afghanistan [Beneficiary: Recipient] by air drops. [Circumstance: Manner] (George W. Bush, Oct. 6, 2001)

(14) I [Carrier] am [Pr. Relational] also proud [Attribute] that coalition victories [Actor] are bringing [Pr. Material] food and water and medicine [Goal] to the Iraqi people. [Beneficiary: Recipient] (George W. Bush, Apr. 3, 2003) 
(15) We [Actor] are taking [Pr. Material] unprecedented measures [Goal] $<$ to spare [Pr. Material] the lives of innocent Iraqi citizens [Goal]>, and are beginning to deliver [Pr. Material] food, water and medicine [Goal] to those in need. [Beneficiary: Recipient] (George W. Bush, Apr. 10, 2003)

(16) In recent days [Circumstance: Location - time], we [Actor] have also brought [Pr. Material] food and water and medicine [Goal] to the Iraqi people. [Beneficiary: Recipient] (George W. Bush, Apr. 5, 2003)

(17) We [Actor] are bringing [Pr. Material] aid [Goal] to the long suffering people of Iraq [Beneficiary: Recipient], and we [Actor] are bringing [Pr. Material] something more [Goal]: we [Actor] are bringing [Pr. Material] hope. [Goal] (George W. Bush, Apr. 5, 2003)

In Examples 1-17, the citizens of Afghanistan and Iraq are portrayed as those who will benefit from the actions taken by the USA (and also from the outcomes of the actions that are represented as the Goals of Material processes). The Beneficiaries: Recipients can benefit from receiving basic material aid ("food", "water", "medicine", "supplies", "emergency rations", "immediate humanitarian assistance"), as well as from delivering "universally acceptable norms and values" (Cap 2008: 102) such as "freedom" in (3) and (11), "friendship" (12), or "strength" and "hope" presented in (4) and in (5) - in these examples the values are to be transferred to unspecified groups of the Beneficiaries: Recipients. In this way, the speaker presents the "human features" of the 'Our' group and presents the division between the regimes' prominent representatives and ordinary citizens (the Beneficiaries: Recipients) who are not the principal objectives of the military operations. Lazar and Lazar (2007: 60) state that in such patterns of transitivity "America represents itself as a hero/savior, who liberates people from tyranny".

This aspect can be also observed in the selections of dynamic Material processes in which the USA is involved and also in its resolution to act. The position of the Actor in clauses 1-17 is occupied by the USA (or by the US military and the coalition partners, or by "coalition victories", respectively), which implies an active role and "dynamic forces in an activity" (Van Leeuwen 2008: 33). In this respect, Van Leeuwen (ibid.) proposes the notion of 'Activation'. Activation can be "realized by grammatical participant roles, by transitivity structures in which activated social actors are coded as actor in material processes" (ibid.). In George W. Bush's discourse, activation is realized with the help of Material processes such as "drop" (1), "bring" (11), (13), (16), (17), or "deliver" (2), (7), (10), in which the USA is involved and which also indicate its determination to provide help to the Beneficiaries: Recipients. The support that is intended 
for the Beneficiaries: Recipients corresponds to the general policy of the Bush administration which concerns the process of rebuilding Iraq and Afghanistan and these examples also show an active involvement of the USA in the process of reconstruction.

The power of the USA in the role of the Actor is further reinforced by presenting its ability to directly confront the enemies and at the same time by its capabilities to provide help and resources to the Beneficiaries in the countries where the military actions took place. Therefore, the USA is construed as an active participant that is able to participate at two fronts - in the military actions against the enemies and also in providing humanitarian assistance to ordinary citizens in Afghanistan and in Iraq who are presented in the participant roles of the Beneficiaries: Recipients. Thus, George W. Bush widens the scope of the activities of the USA in the territories in which the military operations took place.

According to Cap (2008: 40), this "description of the massive concentration of military and logistic actions stresses the historic character of the moment". This may be also associated with the "noble cause" (El-Hussari 2010: 108, italics in the original) of the US army.

The Beneficiaries: Recipients of the actions in which the USA is involved are characterized as "the starving and suffering" (1), "the hungry" (7), "the sick" (10), "those in need" (15) or "the long suffering" (17) which points to an inhuman treatment of the civilian population and to negative effects of the rule of Taliban in Afghanistan and of Saddam Hussein in Iraq. However, the USA as the activated social actor can contribute to the improvement of the living conditions of the Beneficiaries: Recipients. In this respect, Cushman (2005: 2) notes that "coming to the rescue and aid of a people who had been subjected to decades of brutality and crimes against humanity is entirely consistent with the basic liberal principle of solidarity with the oppressed and the fundamental humanitarian principle of rescue". Thus, the 'Our' group acts in accordance with moral tenets and aims to reduce the suffering of ordinary people.

As regards tense, certain examples in which the USA is involved are "only minimally concerned with the past" (Butt, Lukin \& Matthiessen 2004: 274). This aspect can be observed in (1), (3-5), (9-11), (13), which present "what the US "will do" (ibid.). The use of the future tense in these clauses presents a strong resolution to take the action and gives the power to act in the near term. According to Cap (2008: 37), "such a construal of the future helps accept the administration's view of prospective events as logically inevitable". 


\section{2 'Them' in the roles of the Actors in Material processes - the people of Afghanistan and Iraq in the participant roles of the Beneficiaries: Recipients}

The actions and the Goals of the processes of the members of the 'Them' group towards their own citizens are unfavourable for the Beneficiaries: Recipients, as can be observed in Examples (18), (19) and (20). The actions of the regimes in Afghanistan and Iraq "are invariably denoted as brutal and destructive" (Bartolucci 2012: 568). In this way, the speaker points to the abuse of power of the Actors and negatively depicts the regimes in both countries. The enemy is presented as "the responsible actor" (Oddo 2011: 295) for bringing essentially negative elements and suffering to the Beneficiaries: Recipients in the societies that they govern. Consequently, the Beneficiaries: Recipients (the people of Afghanistan and Iraq) cannot benefit from the actions of their rulers and when these actions are transferred to the Beneficiaries: Recipients, the situation in which they live worsens.

According to Lazar and Lazar (2004: 232), in this organization of society "victims [...] also include internal civilian populations, which goes to show that nobody is safe from the tyranny". Totalitarian features of the regimes are conveyed with the Goals of Material processes which include "misery", "terror", or "war", "fear" and "torture". The nature of the Goals that are employed within Material processes clauses works to "vilify and demonize" (Oddo 2011:296) the 'Them' group. The Goals also "identify a foreign, dictatorship-based ideology" (Cap 2008: 41). In the following examples, the Beneficiaries (the people of Afghanistan and Iraq) are deprived of all their power, they are exposed to the power of the Actors and are victims of their activities as a result of which their living conditions deteriorate.

(18) The Taliban regime [Actor] has brought [Pr. Material] nothing but fear and misery [Goal] to the Afghan people. [Beneficiary: Recipient] (George W. Bush, Oct. 10, 2001)

(19) Our enemies [Actor] have brought [Pr. Material] only misery and terror [Goal] to the people of Afghanistan [Beneficiary: Recipient] and now [Circumstance: Location - time] they [Actor] are trying to export [Pr. Material] that terror [Goal] throughout the world. [Circumstance: Location - place] (George W. Bush, Nov. 6, 2001)

(20) Today [Circumstance: Location - time] they [the people of Iraq] [Actor] live [Pr. Material] in scarcity and fear, under a dictator [Circumstance: Locationplace] [who [Actor)] has brought [Pr. Material] them [Beneficiary: Recipient] nothing but war, and misery, and torture.] [Goal] (George W. Bush, Feb. 26, 2003) 
Oddo (2011: 296) classifies words such as "terror" (19) and "fear" (20) as "the goals they promote, value and aspire to bring about". On the basis of their actions towards civilian population, the rulers of Afghanistan and Iraq are shown "as uncaring about human life" (Lazar \& Lazar 2004: 233), which contributes to negative representation of the 'Them'group. The examples above also suggest that the Beneficiary "should not be taken as necessarily indicating that the participant actually benefits in the usual sense of the word" (Thompson 1996: 103, cf. Bloor \& Bloor 2004: 113, Halliday 2014: 239).

\subsubsection{The Iraqi regime - terrorism link: 'Them' in the participant roles of the Beneficiaries: Recipients and in the role of Actors}

The alleged link between the Iraqi regime and the terrorist networks was presented as one of the principal arguments for the legitimisation of the military operation in Iraq in March 2003. Cap (2008: xii) notes that "the strategy of imposing, mixing or otherwise playing with sociopolitical enemy identities on the world stage" can be an effective tool in political discourse.

The speaker employs the participant role of the Beneficiary: Recipient in clauses with participants who are linked to the Iraqi regime and who can benefit from activities related to "giving" or "providing" that are performed by the Iraqi regime in the participant role of the Actor. By presenting this pattern of the participant roles, the speaker attempts to establish discursive connection between the Iraqi regime and terrorism, and he also demonizes the Iraqi regime, as the regime itself supports the threat to the USA and to the world. Fairclough and Fairclough (2012: 96) note that one of the arguments against the Iraqi regime was that it "posed a threat to the world through its connections to global terrorism". In a similar vein, Holland (2013: 142) suggests that "the Bush administration repeatedly asserted Iraq's link to terrorism".

The presentation of 'Them' in the roles of the Actors, their Goals and the nature of the participant role of the Beneficiary: Recipient provide a useful strategy for negative presentation of the 'Them' group on the basis of the link of the Iraqi regime to terrorism. The clauses that feature this link are presented below:

(21) Over the years [Circumstance: Location - time], Iraq [Actor] has provided [Pr. Material] safe haven [Goal] to terrorists such as Abu Nidal [Beneficiary: Recipient], whose terror organization [Actor] carried out [Pr. Material] more than 90 terrorist attacks [Goal] in 20 countries [Circumstance: Location-place] that killed or injured [Pr. Material] nearly 900 people, including 12 Americans. [Goal] (George W. Bush, Oct. 7, 2002) 
(22) Saddam Hussein [Actor] is harboring [Pr. Material] terrorists and the instruments of terror, the instruments of mass death and destruction. [Goal] And he [Phenomenon] cannot be trusted. [Pr. Mental] The risk [Carrier] is [Pr. Relational] simply too great [Attribute] that he [Actor] will use [Pr. Material] them [Goal], or provide [Pr. Material] them [Goal] to a terror network. [Beneficiary: Recipient] (George W. Bush, Oct. 7, 2002)

(23) Iraq [Actor] has also provided [Pr. Material] safe haven [Goal] to Abu Abbas [Beneficiary: Recipient], [who [Carrier] was [Pr. Relational] responsible [Attribute] $<$ for seizing [Pr. Material] the Achille Lauro and killing an American passenger $>$ ]. [Goal] (George W. Bush, Oct. 7, 2002)

(24) Iraq [Actor] could decide [Pr:-] on any given day [Circumstance: Time] to provide [- Pr. Material] a biological or chemical weapon [Goal] to a terrorist group or individual terrorists. [Beneficiary: Recipient] (George W. Bush, Oct. 7, 2002)

(25) It [the Iraqi regime] [Actor] has given [Pr. Material] shelter and support [Goal] to terrorism [Beneficiary: Recipient] and practices [Pr. Material] terror [Goal] against its own people. [Circumstance: Cause - behalf] (George W. Bush, Oct. 7, 2002)

(26) He [Saddam Hussein] [Actor] provides [Pr. Material] funding and training and safe haven [Goal] to terrorists [Beneficiary: Recipient] [who [Actor] would willingly [Circumstance: Manner] deliver [Pr. Material] weapons of mass destruction [Goal] against America and other peace-loving countries.] [Circumstance: Cause - behalf] (George W. Bush, Mar. 8, 2003)

(27) Secretly, and without fingerprints, [Circumstance: Manner] he [Saddam Hussein] [Actor] could provide [Pr. Material] one of his weapons [Goal] to terrorists [Beneficiary: Recipient], or help [Pr. -] them [Actor] develop [Pr. - Material] their own. [Goal] (George W. Bush, Jan. 28, 2003)

(28) By seeking weapons of mass destruction [Circumstance: Manner], these regimes [Actor] pose [Pr. Material] a grave and growing danger. [Goal] They [Actor] could provide [Pr. Material] these arms [Goal] to terrorists [Beneficiary: Recipient], giving [Pr. Material] them [Beneficiary: Recipient] the means [Goal] $<$ to match [Pr. Material] their hatred.> [Goal] (George W. Bush, Jan. 29, 2002)

Hodges (2007: 83) refers to the process of discursive connection between Iraq and terrorist networks (namely Al-Qaeda) as "adequation" (italics in original). Adequation contributes to "socially recognized sameness" (Hodges 2011: 66) and it can be also set up on the basis of the involvement of Iraq in the participant role of the Actor and of terrorists in the roles of the Beneficiaries: Recipients. According to Cap (2008: 138), "Iraq and terrorists are conflated" on the basis of "lasting cooperation" which contributes to the establishing of "shared identity" 
(ibid.). Cap (2008: xii) observes that the "conflation narrative has legitimised the Bush administration's policy of the regime change in Iraq". At the same time, "connecting Iraq with international terrorism" contributes to "criminalisation" of the enemy (Chouliaraki 2007: 5-6, italics in the original).

The connection between Iraq and terrorist networks that is presented reinforces the speaker's argument against 'Them' since the Iraqi regime is portrayed as the source of support for other enemies of the USA that take the roles of Beneficiaries: Recipients. The alleged connection between terrorist groups and Iraq (and Afghanistan as well) also served as one of the reasons for military interventions into both countries.

The Actors in Material processes include Iraq and Saddam Hussein who is presented as "the sole actor" (Oddo 2011: 299), as in (22), (26) and (27). 'They' are involved in processes such as "give" (25), "provide" (21-24), which implies that the activities of the Iraqi regime are directed at the development of cooperation with the terrorist networks or individuals. Oddo (2011: 307) notes that the Iraq "donates goods to and performs services for an inherently evil Beneficiary: terrorists". The aspect related to donation is manifested in the Goals of the enemies' actions that represent the transfer of goods (Halliday 2014). As a result, members of the terrorist networks can benefit from the supply of various resources that are presented as the Goals (e.g. "weapons", "arms", "shelter", "funding") of material nature provided by the Actors. Thus, the enemies in the roles of the Beneficiaries: Recipients are not just passive participants; they can benefit from various Material processes and resources as a result of which their power (and consequently possible danger that they pose) increases. The threat that arises from the process of the accumulation of material resources for the Beneficiaries: Recipients (i.e. enemies) may "enact the aura of physical danger" (Cap 2008: 41). Providing support for the enemies is also considered as one of "the central criteria for classifying a nation as a "rogue state" as noted by Schubert (2014: 326).

In (24) and (28), the speaker indicates the efforts of the Iraqi regime to provide chemical weapons and the weapons of mass destruction (as the Goals) to the terrorists who are in the role of the Beneficiaries: Recipients. Hodges (2007: 72) suggests that the "issues of "terrorist groups" and military "weapons of mass destruction" are in G.W. Bush's discourse "inseperable". These two aspects are interrelated because "Iraq's potential for WMD and the issue of international terrorism parallel each other rhetorically to the effect that the issue of terrorism is constructed as a natural concominant to Iraq's military capabilities". The coordinated efforts of the enemies, in their roles of the Actors and of the receivers 
of benefits provided by the Iraqi regime represent a threat to the security in the world.

The Beneficiaries: Recipients of the actions of the Iraqi regime are mostly characterized "through the generic category of "terrorist" (Butt, Lukin \& Matthiessen 2004: 272). Bartolucci (2012:570) notes that "[i]n Bush's speeches labels are absolute - once an event is represented as 'terrorism' and someone as 'terrorist', there is not much else to be known". Similarly, Schubert (2014: 320) suggests that "terror" belongs to "principal negative values mentioned in Bush's addresses after 9/11". George W. Bush's employed those labels in the majority of examples from (21-28), thus demonizing the 'Them' group.

With the employment of the participant Beneficiary: Recipient, George W. Bush was able to highlight the participation of the Iraqi regime in the role of the Actor that provides its sources to terrorist networks or identified specific individuals associated with terrorism, for example, Abu Nidal (21) and Abu Abbas (23), who could benefit from receiving material aid and support from the Iraqi regime.

\section{Conclusion}

George W. Bush's discourse after 9/11 was primarily built up on the basis of the positive presentation of 'Us' and on the demonisation of the 'Other' and it constructed the ideological ground for President's rhetorical strategy from September 11, 2001 onwards. This paper has presented the application of the system of transitivity in the process of discursive formation of two opposing camps - 'Us' and 'Them' in George W. Bush's discourse. The focus has been placed on the construction of dichotomous representation with the employment of the participant Beneficiary: Recipient. Despite the fact that the Beneficiary as a participant in Material processes lacks the direct power to bring about the processes of an actional type, it may serve as a useful device in the process of discursive construction and depiction of 'Us' and 'Them'.

The dichotomous representation in discourse can be also constructed on the basis of the nature of the involvement of the Actors in Material processes with the Beneficiaries: Recipients. In George W. Bush's discourse, 'Our' actions and efforts are designed to provide support for the civilian population of Afghanistan and Iraq. Thus, the United States is construed as the source of humanitarian support and help for the citizens of Afghanistan and Iraq who are in the roles of the Beneficiaries: Recipients. With the help provided by the USA, the status of the Beneficiaries: Recipients improves. At the same time, the USA is presented as the actor that is able to extend the scope of its actions in the regions. 
On the contrary, the participant role Beneficiary: Recipient also serves as a means of providing the discursive connection between the Iraqi regime and terrorist networks - the Beneficiaries represented by terrorists could benefit from various Material processes and resources provided by the Actor - the Iraqi regime. Consequently, the help provided by the Actors increases the capacity to threaten the USA. Negative aspects of benefiting could be also observed in the actions of cruel nature that were performed by the rulers in Afghanistan and Iraq towards their own citizens. Therefore, the civilian population of these two countries in the role of the Beneficiary: Recipient was exposed to the violent treatment. These activities of the Iraqi regime contributed to negative presentation of the 'Them' group. Overall, the participant role Beneficiary reflected the intentions of George W. Bush's discourse after September 11, 2001 - to demonize 'Them' and to highlight positive qualities and the leading role to 'Us'.

\section{References}

Bartolucci, V. (2012) 'Terrorism rhetoric under the Bush administration: Discourses and effects.' Journal of Language and Politics 11/4, 562-582.

Bloor, T. and Bloor, M. (2004) The Functional Analysis of English. A Hallidayan Approach. $2^{\text {nd }}$ ed. London: Arnold.

Butt, D., Lukin, A. and Matthiessen, C. M. I. M. (2004) 'Grammar - the first covert operation of war.' Discourse and Society 15/2-3, 267-290.

Cap, P. (2008) Legitimisation in Political Discourse: A Cross-Disciplinary Perspective on the Modern U.S. War Rhetoric. $2^{\text {nd }}$ ed. Newcastle: Cambridge Scholar Press.

Chouliaraki, L. (2007) 'Introduction: The soft power of war. Legitimacy and community in Iraq war discourses.' In: Chouliaraki, L. (ed.) The Soft Power of War. Amsterdam: John Benjamins. 1-10.

Cushman, T. (2005) 'Introduction: The liberal-humanitarian case for the war in Iraq.' In: Cushman, T. (ed.) A Matter of Principle. Humanitarian Arguments for the War in Iraq. Los Angeles: University of California Press. 1-26.

El-Hussari, I. A. (2010) 'President Bush's address to the nation on U.S. policy in Iraq: A critical discourse analysis approach.' In: Okulska, U. and Cap, P. (eds) Perspectives in Politics and Discourse. Amsterdam: John Benjamins. 99-117.

Fairclough, I. and Fairclough, N. (2012) Political Discourse Analysis. A Method for Advanced Students. Oxon: Routledge.

Fontaine, L. (2013) Analysing English Grammar. Cambridge: Cambridge University Press.

Fowler, R. (1991) Language in the News: Discourse and Ideology in the Press. London: Routledge.

Graham, P., Keenan, T. and Dowd, A. M. (2004) 'A call to arms at the end of history: A discourse-historical analysis of George W. Bush's declaration of war on terror.' Online document. 11 March $2017<$ http://eprints.qut.edu.au/7267/1/7267.pdf> .

Halliday, M. A. K. (1967a) 'Notes on transitivity and theme in English, Part 1.' Journal of Linguistics 3/1, 37-81. 
Halliday, M. A. K. (1967b) 'Notes on transitivity and theme in English, Part 2.' Journal of Linguistics 3/2, 199-244.

Halliday, M. A. K. (1976) 'Types of process.' In: Kress, G. (ed.) Halliday: System and Function in Language. London: Oxford University Press. 159-173.

Halliday, M. A .K. (1978) Language as Social Semiotic: The Social Interpretation of Language and Meaning. London: Edward Arnold.

Halliday, M. A. K. (1985) An Introduction to Functional Grammar. London: Edward Arnold.

Halliday, M. A. K. (2014) Halliday's Introduction to Functional Grammar. $4^{\text {th }}$ ed. Revised by Matthiessen, C. M. I. M. Oxon: Routledge.

Halliday, M. A. K. and Matthiessen, C. M. I. M. (1999) Construing Experience through Meaning. A Language-Based Approach to Cognition. London, New York: Continuum.

Halliday, M. A. K., and Webster, J. (2014) Text Linguistics. The How and Why of Meaning. Sheffield: Equinox Publishing.

Hodges, A. (2007) 'The narrative construction of identity. The adequation of Saddam Hussein and Osama bin Laden in the "War on Terror".' In: Hodges, A. and Nilep, C. (eds) Discourse, War and Terrorism. Amsterdam and Philadelphia: John Benjamins. 67-87.

Hodges, A. (2011) The "War on Terror" Narrative: Discourse and Intertextuality in the Construction and Contestation of Sociopolitical Reality. New York: Oxford University Press.

Holland, J. (2013) Selling the War on Terror. Foreign Policy Discourses after 9/11. Oxon: Routledge.

Lazar, A. and Lazar, M. M. (2004) 'The discourse of the new world order: "out-casting" the double face of threat.' Discourse and Society 15/2-3, 223-242.

Lazar, A. and Lazar, M. M. (2007) 'Enforcing justice, justifying force. America's justification of violence in the new world order.' In: Hodges, A. and Nilep, C. (eds) Discourse, War and Terrorism. Amsterdam and Philadelphia: John Benjamins. 45-65.

Leudar, I., Marsland, V. and Nekvapil, J. (2004) 'On membership categorization: 'Us', 'Them' and 'Doing violence' in political discourse.' Discourse and Society 15/2-3, 243-266.

Martin, J. R., Matthiessen, C. M. I. M. and Painter, C. (1997) Working with Functional Grammar. London: Arnold.

Matthiessen, C. M. I. M. (2015) 'Descriptive motifs and generalizations.' In: Martin, J. R. and Yeagan, J. D. (eds) Systemic Functional Linguistics: Critical Concepts in Linguistics 2. Abington, Oxon: Routledge. 295-428.

Oddo, J. (2011) 'War legitimation discourse: Representing "Us" and "Them" in four US presidential addresses.' Discourse and Society 22/3, 287-314.

Schubert, C. (2014) 'Cognitive categorization and prototypicality as persuasive strategies. Presidential rhetoric in the USA.' Journal of Language and Politics 13/2, 313-335.

Thompson, G. (1996) Introducing Functional Grammar. London: Arnold.

Thompson, G. (2013) 'Picking an argument: Politicians' choice of persuasive strategies.' In: Fontaine, L., Barlett, T. and O'Grady, G. (eds) Systemic Functional Linguistics: Exploring Choice. Cambridge: Cambridge University Press. 226-246.

Urbach, C. (2013) " "Choice" in relation to context: A diachronic perspective on cultural valeur.' In: Fontaine, L., Barlett, T. and O'Grady, G. (eds) Systemic Functional Linguistics: Exploring Choice. Cambridge: Cambridge University Press. 300-317. 
Van Leeuwen, T. (1996) 'The representation of social actors.' In: Caldas-Coulthard, C. R. and Coulthard, M. (eds) Text and Practices: Readings in Critical Discourse Analysis. London: Routledge. 32-71.

Van Leeuwen, T. (2008) Discourse and Practice: New Tools for Critical Discourse Analysis. Oxford: Oxford University Press.

Wilson, J. (1990) Politically Speaking. The Pragmatic Analysis of Political Language. Oxford: Basil Blackwell.

Marek Hampl is Assistant lecturer at Department of English Language and Literature, University of Žilina in Žilina, Slovakia. His research interests include the analysis of political discourse and the area which is related to the doctrines of American foreign policy with the focus on the Cold War period.

Address: Mgr. Marek Hampl, Ph.D., University of Žilina in Žilina, Faculty of Humanities, Department of English Language and Literature, Univerzitná 8215/1, 01026 Žilina, Slovak Republic. [e-mail: marek.hampl@fhv.uniza.sk] 